\title{
Changes in the nutritional value of the smoked grass carp fillets during refrigerator storage \\ Sabry M. Shehata ${ }^{1}$, Mohamed H. Ghanem ${ }^{1}$, Abdelrahman S. Talab ${ }^{2}$ and Mahmoud M. Abbas ${ }^{1}$
}

1- Marine Biology branch, Zoology Depart., Faculty of Science, Al-Azhar Univ., Cairo, Egypt

2- National Institute of Oceanography and Fisheries

\begin{abstract}
The aim of this study is to investigate the changes in the nutritional value of the smoked grass carp fillets during refrigerator storage for 35 days. Samples of Fresh grass carp fish (Ctenopharyngodon idella) were brought from aquaculture at Kafer El-Shikh Government, Egypt. The proximate composition and physicochemical assessments of the fresh and smoked fish were analyzed, after preparation (zero time), 10, 20, 30 and 40 days of storage.

The results indicated significant differences $(\mathrm{p}<0.05)$ in the proximate composition and physicochemical assessments of the smoked and fresh samples. The nutritional value, except moisture, in the smoked carp fillets decreased with increasing storage time. However, the physicochemical quality aspects in the smoked grass carp during refrigerator storage increased with increasing storage time and decreased with increasing salt concentration during different storage time.
\end{abstract}

Key words: Grass carp fillets, hot smoking, chemical composition, refrigerator storage.

\section{INTRODUCTION}

Fish has a high nutritional value for humans. It is mainly composed of water ranging from 60 to $80 \%$, proteins with noble biological value from 15 to $23 \%$, rich in precious mineral and salts such as potassium, phosphor, iron and vitamins $\mathrm{A}$ and $\mathrm{C}$. In addition, the quantity and the composition of fats present differs the fish from other food (Sanfilippo et al.,2011). Fish is important food in countries with long coastlines and extensive inland water resources. In 2000, food from fish contributed $15.9 \%$ to the human diet on a world wide basis. The total world capture production in 2004 was about 95 million tones and of this about 0.9 million tons were from inland waters (FAO, 2006).
Smoking is one of the oldest food preserving methods, with certain temperature and humidity; smoke sourced from plant material is applied to food. Smoking not only increases resistance of food but changes appearance, taste and smell of foods. Various pre-treatments prior to smoking such as salting and drying and/or after treatments e.g., cooking, marinating are applied in the industry. However, smoking is not an absolute preserving method. For this reason, the quality of raw material, the concentration of salt, water activity of the fish, heat through the smoking process, the quantity of smoke, the way of packaging, hygienic circumstances and heat of storage have important effects reducing the risk of deterioration (Kaya and Erkoyuncu, 1999). 
Grass carp fish represent one of the most important aquaculture fish in Egypt. It has enjoyed and widely acceptability in most parts of the country because of its unique taste, flavour and good texture. Therefore, the purpose of this study was to investigate the nutritional value changes of hot smoked grass carp fish at cold storage conditions. Also, to evaluate the effect of hot smoking on the physico-chemical properties of smoked grass carp fillets.

\section{MATERIALS AND METHODS}

\section{Collection of samples:}

Approximately $(10 \mathrm{~kg})$ of fresh grass carp (Ctenopharyngodon idella) were purchased from aquaculture at Kafer ElShikh Government, Egypt during September 2016. Fresh fish samples were carefully washed with potable water then packed in ice boxes and transported to Fish Processing and Technology Laboratory, National Institute of Oceanography and Fisheries, ElKanater El-Khiria City, El-Qaluobia Governorate, Egypt. The average of total lengths and weight (Mean \pm SD) of grass carp fish were $41.37 \pm 4.04$ and $1291.39 \pm 12.23$, respectively. Upon arrival fish samples were re-washed thoroughly with potable water beheaded, gutted, filleted and rewashed carefully and drained.

Hot smoking processing:

Grass carp fillets were weighed, washed and divided in two groups (A \& B). Group A was immersed in brine (1:1) containing $10 \%$ of sodium chloride at room temperature for two hours and Group B was immersed in brine $(1: 1)$ containing $16 \%$ of sodium chloride at room temperature for two hours. Each fillet groups was rinsed with tap water for $1 \mathrm{~min}$ to remove the excess salt. Each fillet groups was dried in dryer at room temperature $\left(20-25^{\circ} \mathrm{C}\right)$ for two hours. Salted samples were subjected for hot smoking in a laboratory smokehouse in Shakshouk Fish Research Station, National Institute of Oceanography and Fisheries. The smokehouse had inside dimensions of $1.20 \times$ $1.0 \times 3.5 \mathrm{~m}$. Metal boarded plate was used above the smoke source by $75 \mathrm{~cm}$ to filtrate of smoke. Fish fillets were hooked above the smoke source by about $150 \mathrm{~cm}$. Hot smoking process was continued for 5-6 hr at $50-90^{\circ} \mathrm{C}\left(2 \mathrm{hr}\right.$ at $50^{\circ} \mathrm{C}, 2 \mathrm{hr}$ at $60-80^{\circ} \mathrm{C}$ and the remained period at $90^{\circ} \mathrm{C}$ (Abd ElMageed, 1994).

The smoking time, temperature and ambient conditions were monitored using a thermometer during the smoking operation. After smoking, these samples allowed to cool at ambient temperature and packaged in air tight polythene bags and kept in perforated plastic containers and kept in cold condition (refrigerator) at $4^{\circ} \mathrm{C}$ for 40 days and chemical composition and physicochemical attributes analysis were carried out immediately after preparation (zero time), $10,20,30$ and 40 days of storage.

\section{Analysis:}

The nutritional values (moisture, protein content, crude fat, total ash, carbohydrates and total calories) of samples were determined according to the methods described by AOAC, (2012). $\mathrm{P}^{\mathrm{H}}$ analysis was done by the method of (Goulas et al., 2005) using $\mathrm{pH}$ meter (HANNA, pH213). Thiobarbituric acid (TBA) value was determined by the distillation method 
outlined by Tarladgis et al. (1960). Total volatile bases nitrogen (TVBN) in samples was described by Mwansyemela (1973).

\section{RESULTS AND DISCUSSION 1. Effect of smoking process on the quality of fish fillets:}

The measurement of some nutritional values such as protein contents, carbohydrates, lipids, moisture content and ash content are often necessary to ensure that they meet the requirements of food regulations and commercial specifications (Waterman, 2000).

In the present study, the filleting yield of grass carp fillets was $55.26 \%$. This result was higher than that reported by Abdel-Aal (1996) who recorded that, the yield of common carp fish was $47.19 \%$. Gall et al. (1983) reported that, the yield of individual fish is influenced by a variety of physiological and environmental factors that determine the amount of muscle tissue present in everyone.

Nutritional values of unsmoked (fresh sample) and smoked grass carp samples showed statistical differences. The proximate compositions of fresh grass carp showed lower average in protein, fat, ash content, and carbohydrates than smoked grass carp fillets, this may be due to water loss during smoking. Similar findings were reported by Bhuiyan et al. (1986) in Atlantic mackerel, Unlusayin et al.(2001) in European eel, Koral et al. (2010) in Atlantic Bonito (Sarda sarda) and Ahmed et al.(2010) in Clarias lazera.

The moisture content of fresh grass carp was higher than smoked grass carp fillets (group A and group B) and it was decreased with increasing salt concentration being; $\quad 78.11 \pm 0.09, \quad 48.22 \pm 0.09$ and $48.01 \pm 0.06$, respectively. The decreasing in moisture content may be due to the brining and smoking processes. Similar observation was also found for hot smoked bonito fish by Kaya and Erkoyuncu (1999), Duyar et al. (2008) and for smoked mackerel by Bhuiyan et al. (1986). Cardinal et al. (2001) who suggested moisture content of smoked fish to be below $65 \%$. The present result for moisture content was lower than suggested value. This might be due to the various treatments prior to smoking process such as salting and drying. Also, Koral et al. (2010) recorded that, the moisture content of fresh fillets of Atlantic Bonito (Sarda sarda) was higher than smoked one and being $67.71 \pm 0.40$ and $57.13 \pm 0.15$, respectively.

The present result revealed that, the crude protein in the fresh grass carp was lower than smoked grass carp fillets (group A and group B) and it increased with increasing salt concentration being; $16.55 \pm 0.04,23.38 \pm 0.08$ and $23.42 \pm 0.03$, respectively. The increase in crude protein level can be explained by Kumolu-Johnson et al.(2010) who stated that, smoking resulted in concentrating crude protein components of fish. This concentration was resulted from the loss of moisture after the smoking process (Koraland Tufan, 2009). This result agrees with Franco et al. (2010) who mentioned that protein content in the smoked fillets increases than the fresh fillets.

Lipid content acts as an absorbent agent of the aromatic substances present in the smoke. Results mentioned that, the lipid content of fresh grass carp was lower than 
that in smoked grass carp fillets (group A and group B) and it increased with increasing salt concentration being; $2.31 \pm 0.01, \quad 13.88 \pm 0.02$ and $14.66 \pm 0.01$, respectively. Lipid increase was observed in smoked fillets than the fresh one and is caused by dehydration (decreased moisture content) due to smoking. This result agrees with Franco et al. (2010) who mentioned that lipid content in smoked fillets increases than the fresh fillets.

Ash content in food is inorganic residue reaming after ignition of organic matter. The current result revealed that, ash content of fresh grass carp was higher than smoked grass carp fillets (group A and group B) and it increased with increasing salt concentration being; $1.87 \pm 0.01$, $6.38 \pm 0.03$ and $8.50 \pm 0.04$, respectively. This may be due to brining step, used as pretreatment, which is the main reason for this increment. Similar result was recorded by Salán et al. (2006) and Franco et al. (2010).

The present result revealed that, the carbohydrates content in the fresh grass carp was lower than smoked grass carp fillets (group A and group B) and it decreased with increasing salt concentration being; $1.16 \pm 0.01, \quad 8.14 \pm 0.06$ and $5.41 \pm 0.07$, respectively. This result agrees with Akintola et al. (2013) who recorded that, carbohydrates content in the smoked fillets increases more than that in the fresh fillets.

The total calories was lower in current fresh grass carp (91.63 \pm 1.49 $\mathrm{kcal} / 100 \mathrm{~g})$ than smoked grass carp which ranged between $218.47 \pm 1.33 \mathrm{kcal} / 100 \mathrm{~g}$ in Group A and 225.64 $\pm 2.22 \mathrm{kcal} / 100 \mathrm{~g}$ in Group B. This result agrees with Ojewola et al. (2003) who observed that processing methods accounted for the differences observed in the composition and gross energy content of all test samples which they studied. Aberoumad and Pourshafi (2010) observed that the lower the percentage of water denotes a greater lipid and protein content resulting into higher energy density of the fish. This suggests that since the smoked fish had the highest protein content, it implies that energy levels would also be high.

The $\mathrm{pH}$ values of fresh grass carp was higher than smoked grass carp fillets (group A and group B) and it decreased with increasing salt concentration being; $6.55 \pm 0.01, \quad 6.15 \pm 0.03$ and $5.52 \pm 0.02$, respectively. This reduction in $\mathrm{pH}$ after smoking process may be due to carboxylic acids, acetic acid, and other organic acids from $\mathrm{NaCl}$ content during brining or from the smoking wood during smoking. Similar reduction in $\mathrm{pH}$ has been reported by Turan et al. (2008).

TBA values were used for the freshness of fish and fish products. TBA values of fresh grass carp showed lower than smoked grass carp fillets (group A and group B) and it was decrease with increasing salt concentration being; $1.93 \pm 0.01$, $2.54 \pm 0.06$ and 2.04 \pm 0.04 , respectively. However, the maximum allowed level is accepted as $8 \mathrm{mg}$ malonaldehyde/ $\mathrm{kg}$ (Schormüller, 1969). Similar observation reported by Koral et al. (2010) whom recorded that,TBA values in unprocessed fresh bonito increased after the smoking process.

TVB-N values of fresh grass carp showed lower than smoked grass carp fillets 
(group A and group B) and it was decrease with increasing salt concentration being; $4.43 \pm 0.05, \quad 12.42 \pm 0.01$ and $8.88 \pm 0.02$, respectively. However, the maximum limit $35 \mathrm{mg} / 100 \mathrm{~g}$ is generally acceptable (Huss, 1988; Connell, 1990; Lopez-Caballero et al., 2000 ; Kim et al., 2002). Similar observation reported by Koral et al. (2010) whom recorded that,TVB-N values in unprocessed fresh bonito increased after the smoking process.

\section{Nutritional value changes in the} smoked fish during refrigerator storage:

Moisture content in the smoked carp fish increased with increasing storage time and decreased with increasing salt concentration during different storage periods (Fig. 1). This increasing can be attributed to absorption of water from the surrounding since there was no re-drying during storage (Daramola et al., 2007). This result disagree with Cardinal et al. (2001), Mother (1988) and Ahmed et al.(2010) who reported that the moisture content in the smoked fish decreased with increasing storage time.

The crude protein content (Fig. 2) in the smoked grass carp fish decreased with increasing storage time and it was increase with increasing salt concentration during different storage time. This reduction in protein during storage due to water soluble protein diffused out to the surrounding for exosmosis as reported by Hassan et al. (2013). This could be due to gradual degradation of initial crude protein to more volatile products such as total volatile bases, hydrogen sulphide and ammonia (Eyo, 2001). Similar drop in protein concentration was reported for Heterobranchus longifilis (Abolagba et al., 2008). Also, Daramola et al.(2013) found decreasing trend of protein content in hot smoked $C$. gariepinus during storage period. This result disagreed with Ramazan Oğuz (2009) who found that protein content of (Tincatinca) increase to reach $25.6 \%$ during the $28^{\text {th }}$ day of storage.

Lipid content (Fig. 3) in the smoked grass carp fish decreased with increasing storage time and it increased with increasing salt concentration during different storage time. This result agree with Ahmed et al.(2010) and disagree with Ramazan Oğuz (2009) who reported that the fat content of (Tincatinca) increased with increasing storage time.

Ash content (Fig. 4) in the smoked grass carp fish decreased with increasing storage time and increased with increasing salt concentration during different storage time. This may be due to absorbance of moisture and loss of protein. This result disagree with Cardinal et al. (2001) and Ahmed et al.(2010) who stated that relative and significant increases occurred in ash content of smoked fish samples during storage period.

\section{Physico-chemical quality changes in the smoked fish during refrigerator storage:}

The $\mathrm{pH}$ values (Fig. 5) in the smoked grass carp fish increased with increasing storage time and decreased with increasing salt concentration during different storage time. Moderate increase of $\mathrm{pH}$ value of coldsmoked common carp samples at the end of the storage period may be attributed to the higher quantity of basic compounds 
produced by the activity of fish spoilage bacteria (Stohr et al., 2001).

The combined total amount of ammonia $\left(\mathrm{NH}_{3}\right)$, dimethylamine (DMA) and trimethylamine (TMA) in fish is called the Total Volatile Base Nitrogen (TVB-N); its content in fish meat is commonly used for spoilage estimation, and as the main parameter of fish muscle freshness. TVB-N is widely used as an indicator of the degree of lipid oxidation (Daramola et al., 2007; Milijašević et al., 2016). It helps to measure the level of fish spoilage and to explore the shelf life of fish. TVBN are produced by decomposition of proteins into simpler substances (ammonia, trimethylamine, creatine, purine bases and free amino acids) (Viji et al., 2014). The present results indicated that TVB-N values in the smoked carp increased with increasing storage time although samples were within acceptable level for this parameter (Fig. 6). This may be due to gradual degradation of the initial protein to more volatile product such as total volatile base nitrogen (Daramola et al., 2007). The increasing in TVB-N throughout the storage period may be due to microbial activity, storage temperature, absorption of moisture (Nahid et al., 2016). Similar observation was reported by Koral et al. (2010) who reported that TVB-N values increased significantly during cold storage $(\mathrm{P}<0.05)$. Also, the increasing of TVB-N in common carp and bighead carp cold smoked samples during the storage period may be due to TVB-N which is produced mainly during bacterial decomposition of fish meat, the higher content of TVC values in coldsmoked common carp samples may cause higher increase of TVB-N values at the end of experiment. However, TBA values in the smoked carp increased with increasing storage time although samples were within acceptable level for this parameter. Similar observation reported by Beltran et al. (1989), Göktepe and Moody (1998), Goulas and Kontominos (2005), Yanar (2007) and Koral et al. (2010) for different smoked fish products.

During the storage time, the highest values of feder value in the sample of Group $A$ and B (1.98 \pm 0.03 and 1.85 \pm 0.05 , respectively) were recorded at 10 days of storage and the lowest values $(2.77 \pm 0.02$ and $2.72 \pm 0.03$, respectively) were at 40 days of storage. These values fell below the maximum of acceptable feder as indicated by Pearson (1970) who reported that feder value in good quality product should not exceed 4.00. 


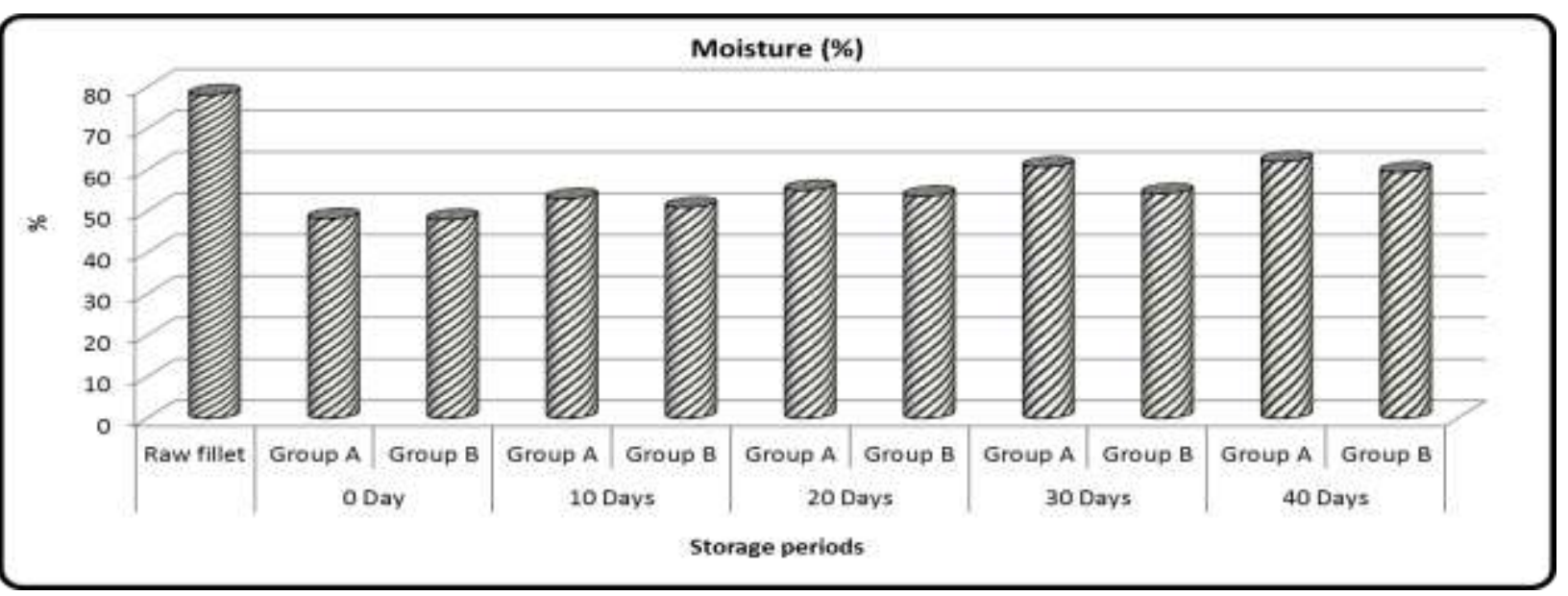

Fig. (1): Changes of moisture (\%, on wet weight basis) in the smoked grass carp during refrigerator storage at $-4{ }^{\circ} \mathrm{C}$ up to 40 days.

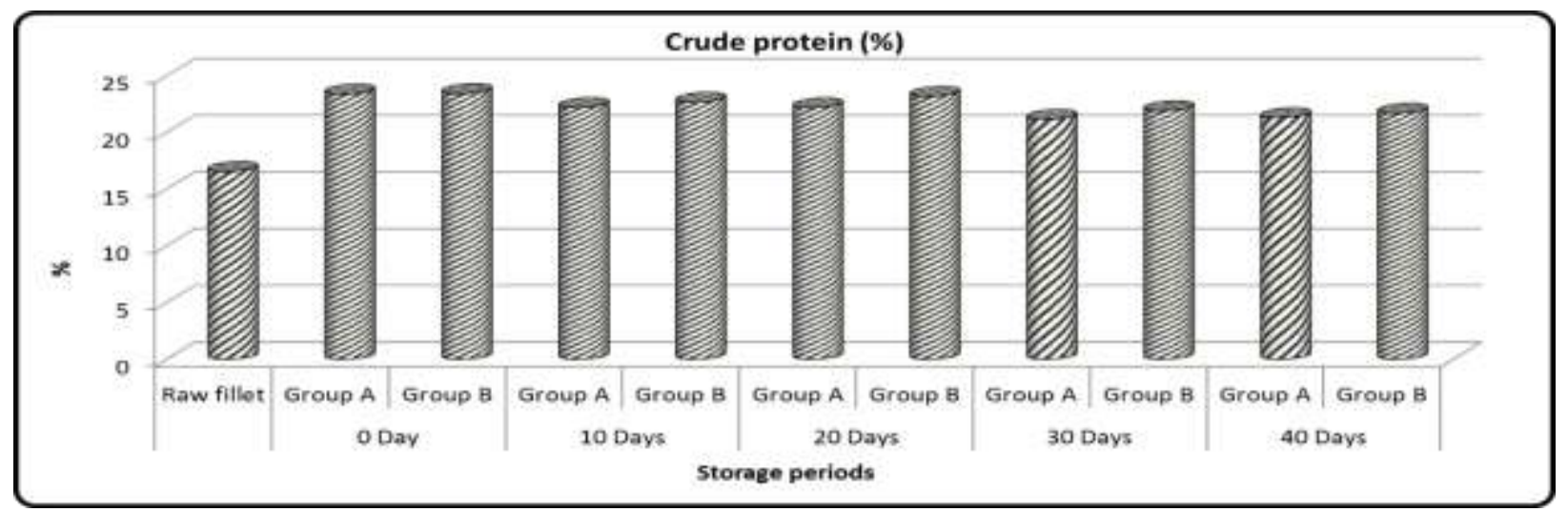

Fig. (2): Changes of crude protein (\%, on wet weight basis) in the smoked grass carp during refrigerator storage at $-4{ }^{\circ} \mathrm{C}$ up to 40 days.

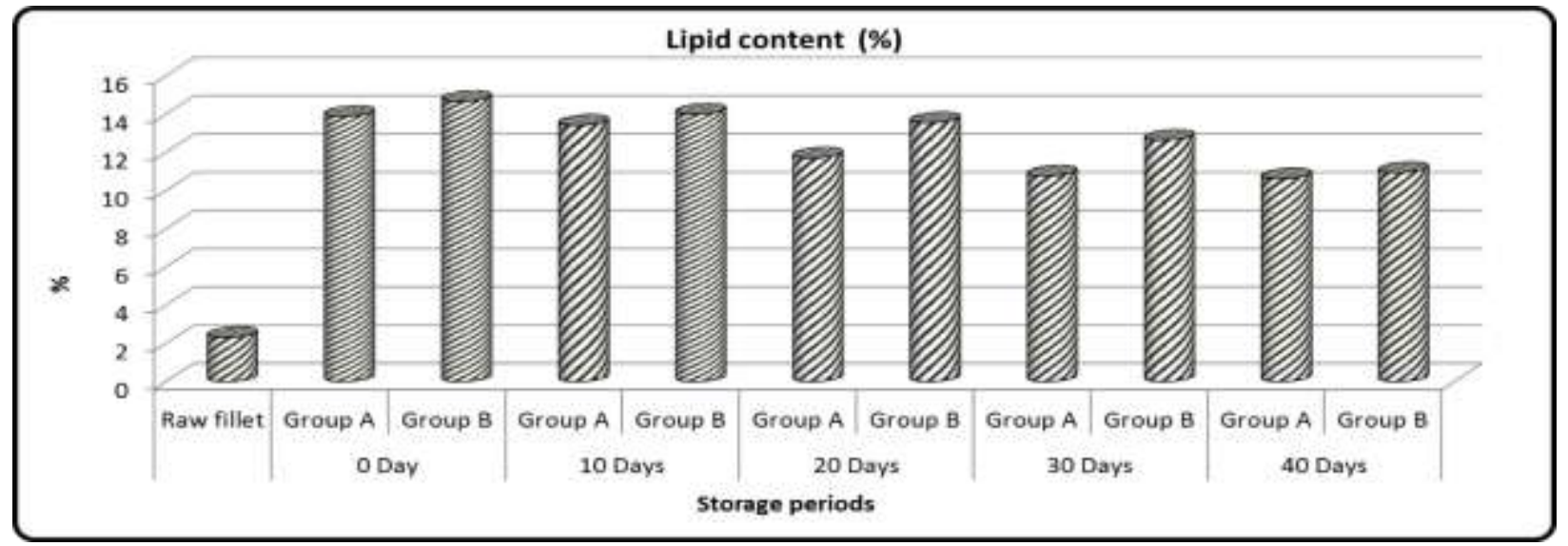

Fig. (3): Changes of lipid content (\%, on wet weight basis) in the smoked grass carp during refrigerator storage at $-4{ }^{\circ} \mathrm{C}$ up to 40 days. 


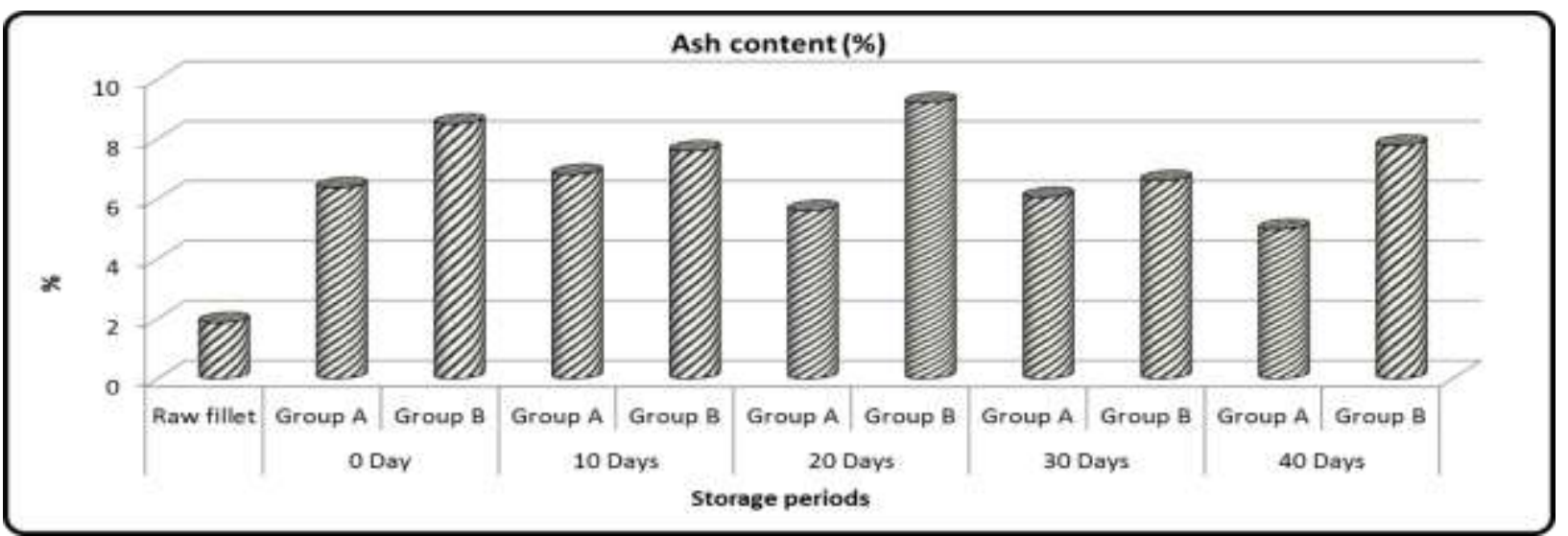

Fig. (4): Changes of ash content (\%, on wet weight basis) in the smoked grass carp during refrigerator storage at $-4{ }^{\circ} \mathrm{C}$ up to 40 days.

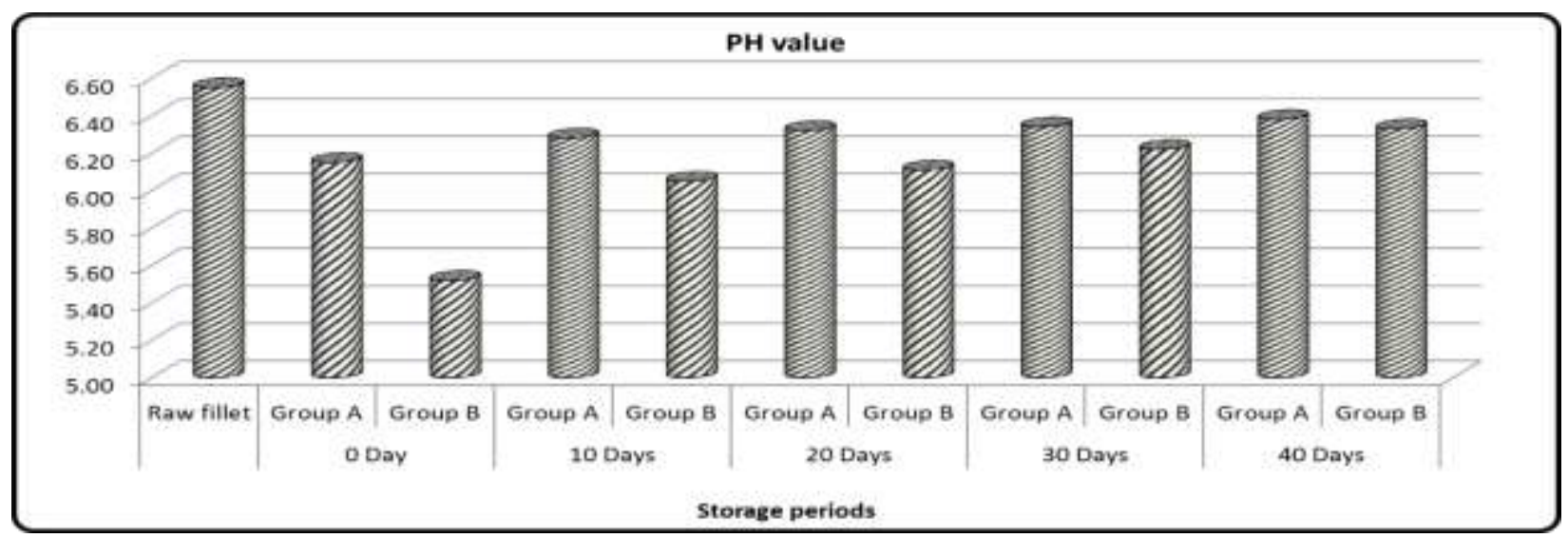

Fig. (5): Changes of $\mathrm{pH}$ in the smoked grass carp during refrigerator storage at $-4{ }^{\circ} \mathrm{C}$ up to 40 days.

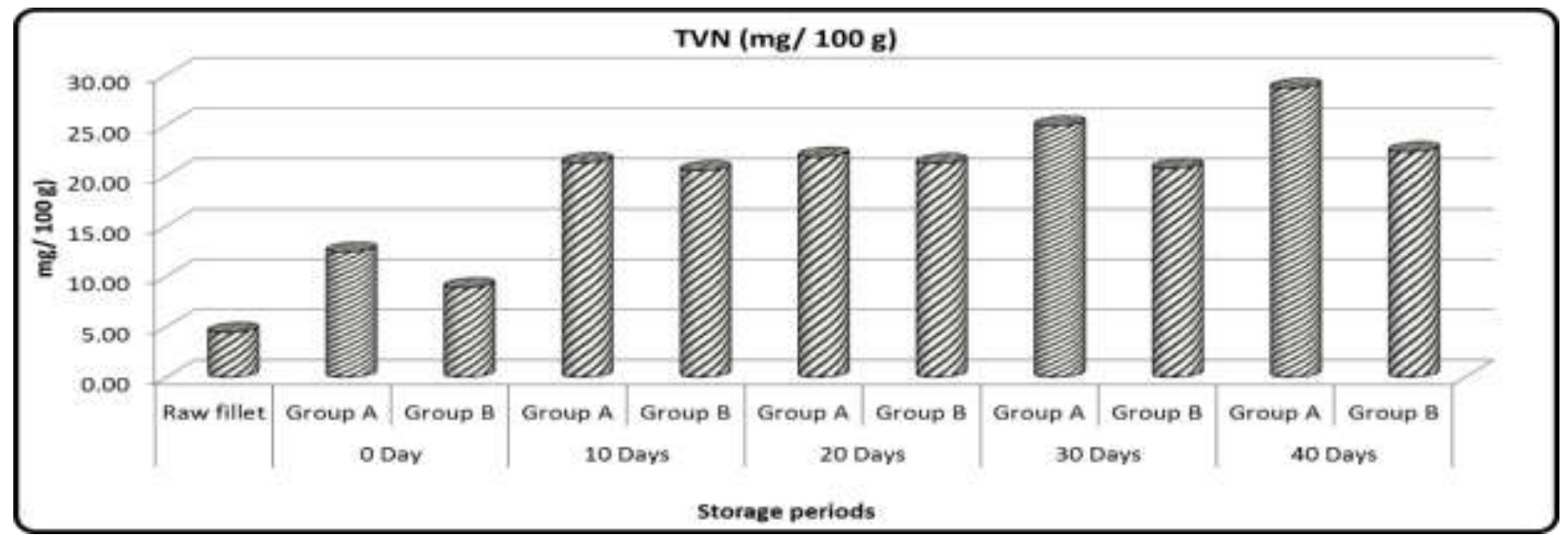

Fig. (6): Changes of total volatile base nitrogen (TVB-N, $\mathrm{mg} / 100 \mathrm{~g}$ ) in the smoked grass carp during refrigerator storage at $-4{ }^{\circ} \mathrm{C}$ up to 40 days. 


\section{REFERENCES}

Abd El-Mageed, S.A. (1994). Chemical and technological studies on fish smoking. M.Sc. thesis, Fac. of Agric., EL-Azhar Univ., Cairo, Egypt.

Abdel-Aal, H. A. (1996). Factors affecting the quality of surimi processed from fresh water fish. Ph.D. Thesis, Faculty of Agricultures, Minia University.

Aberoumad, A. and Pourshafi, K. (2010) Chemical and proximate composition properties of different fish species obtained from Iran. World J. Fish and Mar. Sci., 2: 237-239.

Ahmed, E.O.; Adm, H.T. and Mohammed, K.E. (2010). Investigating the Quality Changes of Hot Smoked Clariaslazeraat Refrigerated Temperature $\left(5 \pm 1^{\circ} \mathrm{C}\right) \mathrm{J}$ ournal of Agriculture and Food Sciences, www.resjournals.org/JAFS, Vol.1(3); pp. 27-32, March 2013

Akintola, S. L.; Brown, A.; Bakare, A.; Osowo, O. D. and Bello,B. O. (2013): Effects of Hot Smoking and Sun Drying Processes on Nutritional Composition of Giant Tiger Shrimp (Penaeus monodon, Fabricius, 1798)Pol. J. Food Nutr. Sci., 2013, Vol. 63, No. 4, pp. 227-237.

AOAC, (2012): Official methods of analysis.Association of Official Analytical Chemists, Inc., Washington, DC, USA.

Beltran, A.; Pelaez, C. and Moral, A. (1989). Keeping quality of vacuum-packed smoked sardine fillets: microbiological aspects. J. of Z. LebensmUntersForsch. 188:232-236.

Bhuiyan, AKM, Ratnayake, WMN, Ackman RG (1986). Effect of smoking on the proximate composition of Atlantic mackerel (Scomberscombrus). J. Food Sci. 51: 327-329.

Bhuiyan, AKM, Ratnayake, WMN, Ackman RG (1986). Effect of smoking on the proximate composition of Atlantic mackerel (Scomberscombrus). J. Food Sci. 51: 327-329.

Cardinal M, Knockaert C, Torrissen O, Sigurgisladottir S, Morkore T, Thomassen M, Vallet JL (2001). Relation of smoking parameters to the yield colour and sensory quality of smoked Atlantic salmon (Salmo salar). Food Res. Int. 34: 537-550.

Cardinal M, Knockaert C, Torrissen O, Sigurgisladottir S, Morkore T, Thomassen M, Vallet JL (2001). Relation of smoking parameters to the yield colour and sensory quality of smoked Atlantic salmon (Salmo salar) . Food Res. Int. 34: 537-550

Connell, J.J., (1990). Methods of assessing and selecting for quality. In Control of fish quality,(3 edition). Oxford: Fishing News Books,pp: 122-150.

Daramola, J. A., Fasakin, E. A. and Adeparusi, E. O. 2007. Changes in Physicochemical and Sensory characteristics of smoke-dried Fish species stored at ambient temperature. African Journal of Food, Agriculture, Nutrition and Development 7: 1-16.

Duyar, HA; Erdem, ME. and Samsun, S, F (2008): The Effects of the Different Woods of HotSmoking Vacuum Packed Atlantic Bonito (Sardasarda) Stored at $4^{\circ}$ C. J. Anim. Vet. Adv. 7: 1117-1122.

Eyo, A. A. (2001): Fish processing technology in the tropics, University of Ilorin Press. 403pp.

FAO. (2006). Fishery Information, Data and Statistics Unit. Capture production: quantities 19502004. Rome. Retrieved from http://www.fao.org/fi/statist/FISOFT/FISHPLUS.asp.

Franco, M.L.R.D.S., Viegas, E.M.M., Kronka, S.N., Vidotti, R.M., Assano, M. and Gasparino, E., 2010. Effects of hot and cold smoking processes on organoleptic properties, yield and composition of matrinxa fillet. RevistaBrasileira de Zootecnia, 39(4), 695-700. 
Gall, K. L.; Otwell, W. S.; Koburger, J. A and Appledorf, H. (1983): Effects of four cooking methods on the proximate, mineral and fatty acid composition of fish fillets. Journal of FoodScience, 48: 1068-1074.

Goktepe, I. and Moody, M.W.1998. Effect of modified atmosphere package on the quality of smoked catfish. Journal of Muscle Foods, 9:375-389.

Goulas AE, Kontaminas MG. Effect of salting and smoking method on the keeping quality of chub mackerel (Scomber japonicus): Biochemical and sensory attributes. Food Chem. 2005; 93:511-520.

Goulas, AE. and Kontominos, MG. (2005): Effect of salting and smoking method on the keeping quality of chub mackerel (Scomber japonicus): biochemical and sensory attributes. Food Chemistry. 93: 511-520.

Kaya, Y. and Erkoyuncu, İ. (1999): Değişik Dumanlama Metotlarının Balık Türlerinin Kaliteleri Üzerine Etkisi. O.M.Ü. Ziraat Fakültesi Dergisi, 14(1): 93- 105.

Kim, Y.M., Paik, H.D. and Lee, D.S. (2002): Shelf-life characteristics of fresh oysters and ground beef as affected by bacteriocin-coated plastic packaging film. Journal of the Science of Food and Agriculture, 82: 998-1002.

Koral, S.; and Tufan, B. (2009): Investigating the Quality Changes of Raw and Hot Smoked Garfish (Belone beloneeuxini, Günther, 1866) at Ambient and Refrigerated Temperatures. Turkish J. Fish. Aquatic Sci. 9: 53-58.

Koral, S.; KÖse, S. and Tufan, B. (2010): The effect of storage temperature on the chemical and sensorial quality of hot smoked Atlantic Bonito (Sardasarda, Bloch, 1838) packed in Aluminium foil. Turkish J. of Fisheries and Aquatic Science 10:439-443.

Kumolu-Johnson, C. A.; Aladetohun, N. F. and Ndimele,P. E. (2010): The effects of smoking on the nutritional qualities and shelf-life of Clariasgariepinus(BURCHELL 1822) African Journal of Biotechnology Vol. 9 (1), pp. 073-076.

Lopez-Caballero, M. E., Perez-Mateos, M., Montero, P. and Borderias, A.J. 2000. Oyster preservation by high- pressure treatment. Journal of Food Protection, 63: 196-201.

Milijašević, M. P.; Babić, J. A.; Vranić, D. V.; Borović, B. R. and Moračanin, S. M. V. (2016): Quality attributes of chilled vacuum-packaged cold-smoked common carp (Cyprinuscarpio) and cold-smoked bighead carp (Hypophthalmichthysnobilis) fllets ACTA VET. BRNO 2016, 85: 195-203.

Mother, T. (1988). Effect of Smoking and Drying on the Nutritive Value of Fish: A Review of Japanese Studies. Burt JR (Ed). Elsevier Applied Science Publishers Ltd, London and New York. pp., 91-120.

Mwansyemela, N. A., (1973). Report on studies of routine analysis for food chemistry. Institute for fishery products TNO at Ijmuiden, Holland, 2nd April to 15th Sept.

Nahid, M. N.; Latifa, G. A.; Chakraborty, S. C.; Farid, F. B. and Begum, M. (2016): Shelf-Life Quality Of Smoke-Dried Freshwater SIS Fish; Chapila (Gudusiachapra, HamiltonBuchanan; 1822) Kaika (Xenentodoncancila, Hamilton-Buchanan; 1822) And Baim (Mastacembeluspancalus, Hamilton-Buchanan; 1822) Stored At Laboratory Condition (26-31 $\left.{ }^{\circ} \mathrm{C}\right)$ IOSR Journal of Agriculture and Veterinary Science (IOSRJAVS) e-ISSN: 2319-2380, p-ISSN: 2319-2372. Volume 9, Issue 3 Ver. I (Mar. 2016), PP 23-32.

Ojewola, G. S., Eburuaja, A. S., Okoye, F.C., Lawal, A. S. and Akinmutimi, A. H. 2003. Effect of inclusion of grasshopper meal on performance, nutrient utilization and organ of Broiler chicken. Journal of Sustainable Agriculture and Environment 5: 19-25. 
Pearson, D. 1970. The Chemical Analysis of Food (6th Edn), p. 604. London: Churchill Publisher.

Salán OE, Juliana AG, Marilia O (2006). Use of smoking to add value to salmoned trout. Braz. Arch. Biol. Technol. 49(1): 57-62

Sanfilippo, M., Reale, A., Ziino, M., Romeo, V., Lembo, E., and Manganaro, A. (2011). Chemical Composition and Nutritional Value of Engraulisencrasicolus (Linnaeus, 1758) Caught by Driftnet "Menaide" along Sicilian Coast: a Natural Food for Mediterranean Diet. World Journal of Fish and Marine Sciences, 3 (1), 44-50.

Schormüller J 1969: Handbuch der lebensmittelchemie (Band IV). Springer Verlag, Berlin Heidelberg - New York.

Stohr, V., Joffraud, J. J., Cardinal, M. and Leroi, F., 2001. Spoilage potential and sensory profile associated with bacteria isolated from cold-smoked salmon. Food Research International, 34, 797-806.

Tarladgis, B. G.; Watts, B. M.; Younathan, M. T. and Dugan, L., (1960):A distillation method for the quantitative determination of malonaldehyde in rancid food, J. of Am. Oil. Chem. Soc., 37: 44-48.

Turan, H., Sonmez, G., Celik, M., Yalcin, K. and Yalcin, M. (2008). The effects of hot smoking on the chemical composition and shelf life of Mediterranean mussel (mytilusgalloprovincialis) under chilled storage. Journal of Food Processing and Preservation, 32, 912-922.

Unlusayin M, Kaleli S, Gülyavuz H (2001). The determination of flesh productivity and protein components of some fish species after hot smoking. J. Sci. Food Agric. 81: 661-664.

Waterman, J. J. 2000: Composition and Quality of Fish, Edinburgh, Torry Research Station.

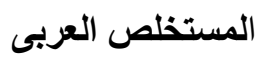


